\title{
Between the project and the everyday: The Guajuviras case
}

\author{
William Mog
}

\section{William Mog}

Architect and urbanist; Academic student at PROPUR/UFRGS; williammog@hotmail.com

\begin{abstract}
Between the Guajuviras Housing Complex project designed due to a housing policy and the daily living of its residents due to the successive occupations and appropriations in time there is a history full of conflicts and tensions. This article aims to rescue this story emphasizing the contrasts within this housing produced and deployed in Canoas/RS between the 1970s and 1980s from the Companhia de Habitação (COHAB) site and the Banco Nacional da Habitação (BNH) and occupied illegally in 17 April 1987. This situation was repeated in other cases in the Região Metropolitana de Porto Alegre (RMPA) and is due to the clash between the strategic actions of those who conceived the project from a policy and tactics who shares the lives place everyday. This relationship is manifested in space perceived practices generating continuities and discontinuities that have an impact on the day-to-day lives. Today what is observed in "Guaju" as it is popularly known is a mosaic of different territories now approach and now turn away due to the daily dynamics developed by the locals.
\end{abstract}

Keywords: project, policy, daily.

\section{Resumo}

Entre o projeto do Conjunto Habitacional Guajuviras concebido em função de uma política habitacional e o cotidiano vivido dos seus moradores em função das sucessivas ocupações e apropriações no tempo há uma história repleta de conflitos e tensões. Este artigo objetiva resgatar tal história enfatizando os contrastes existentes dentro deste conjunto produzido e implantado em Canoas/ RS entre as décadas de 1970 e 1980 a partir da Companhia de Habitação (COHAB) local e do Banco Nacional da Habitação (BNH) e ocupado irregularmente no dia 17 de Abril de 1987. Tal situação se repetiu em outros casos na Região Metropolitana de Porto Alegre (RMPA) e é decorrente do choque entre as ações estratégicas de quem concebe o projeto a partir de uma politica e as ações táticas de quem vive o cotidiano do lugar. Esta relação se manifesta no espaço percebido das práticas gerando continuidades e descontinuidades que repercutem no dia-a-dia das pessoas. Hoje o que se observa no "Guaju" como é popularmente conhecido é um mosaico de territórios distintos que ora se aproximam e ora se afastam em função das dinâmicas cotidianas desenvolvidas pelos moradores.

Palavras-chave: projeto, política, cotidiano.

\section{Resumen}

Entre el proyecto del Complejo de Vivienda Guajuviras diseñado debido a la política de vivienda y la vida diaria de sus habitantes debido a las sucesivas ocupaciones y apropiaciones en el tiempo hay una historia llena de conflictos y tensiones. Este artículo tiene como objetivo rescatar esta historia haciendo hincapié en los contrastes dentro de este complejo producido y implantado en Canoas/RS entre los años 1970 y 1980 en función de la Companhia de Habitação (COHAB) local y del Banco Nacional da Habitação (BNH) y ocupado ilegalmente en 17 de abril de 1987. Esta situa- 
ción se repitió en otros casos en la Região Metropolitana de Porto Alegre (RMPA) y se debe al choque entre las acciones estratégicas de los que concibieron el proyecto a partir de una política y las acciones tácticas de los que viven el cotidiano del lugar. Esta relación se manifiesta en el espacio percibido de las prácticas generando continuidades y discontinuidades que tienen un impacto en la vida del día a día. Hoy en día lo que se observa en "Guaju" como se le conoce popularmente es un mosaico de diferentes territorios que ahora se acercan y ahora se alejan, debido a las dinámicas diarias desarrolladas por los locales.

Palabras-clave: proyecto, política, cotidiano.

\section{Introduction}

7 he present article aims to problematize the relationship between the housing project coming from a housing policy and the local quotidian from a process of occupation highlighting the degree of correspondence between the two. To this end, we intend to work with a housing complex produced in the period corresponding to the 1970s and 1980s in the Metropolitan Region of Porto Alegre (RMPA). This set titled Guajuviras and located in a peripheral region of the municipality of Canoas/RS is analyzed here in function of three complementary topics. Each topic initially presents a theoretical basis. In the first one, the actors between the project and the daily life based on Lefebvre (1991), the second the actions of these actors during the process of historical consolidation based on Certeau (2014) and the third the daily repercussions of this process based on Lefebvre (2001).

The first topic emphasizes the conflicting and disjointed relationship between the hegemonic actors of the conceived space and the everyday actors of the space lived in the housing production of the period of the Military Dictatorship in Brazil. The first group is represented by the National Housing Bank $(\mathrm{BNH})$, the Metropolitan Region Executive Group (GERM) and the Housing Companies (COHABs), while the latter is made up of the inhabitants living on a day-to-day basis. The first group conceives the space from policies, plans and projects respectively, while the second group lives this space by occupying it in daily life.

In the second topic, we aim to problematize this relationship between the actors in function of their actions within the historical process of constitution of the case studied. While hegemonic actors develop actions of a strategic and taxing nature linked to the space conceived, everyday actors react against them from tactical and adaptive actions that reinvent the conceived in 
function of the lived space. This shock will happen in time in different ways producing spatial results antagonistic to each other.

And, finally, in the third topic, it is evident the spatial result in the daily life from the reconstruction history. Here the focus is on the structural, formal and functional issues during the transition from the project of a policy to the daily life of successive occupations. In this process, it is understood that the way in which the conceived space of the project changes in function of the lived space of daily life varies between continuity and discontinuity relations verifiable through the structure-form-function indicator.

Who knew the Housing Set Guajuviras before the occupation and visit it today experiences a reality shock, because of the original project there are only a few traces that dispute space with the shocking changes proposed by the residents themselves over time. It is understood here that the solutions found by the people deserve to be valued because they correspond to the real necessities of the day-to-day that a urban space of quality must attend unlike stereotyped solutions coming from standard programs. Therefore, the article intends to emphasize this process of occupation and mutation of the space and its repercussions in the scope of daily life with the intention of questioning the project guidelines while materialization of a housing policy.

\section{Between hegemonic actors and everyday actors}

The production of space is based on the confrontation between the actor who conceives the space within the scope of the project and the actor who lives such space in the scope of daily life. For Lefebvre (1991), while the conceived space is the representation of space, the lived space is the space of representations. These are interpenetrated within the perceived space that is the space of practices. This conceived-lived-perceived triad, therefore, structures the spatial relationships during the transformations proposed by the clash between actors with distinct interests. These theoretical questions materialize in the housing production in Brazil during the $\mathrm{BNH}$ period emphasized below.

The production of the housing space in Brazil and by extension in the Metropolitan Region of Porto Alegre (RMPA) during the 1970 s and 1980 s was marked by the Military Regime and by a strong tax and control policy that covered the entire brazilian national 
territory. This policy linked to this military period presented several sectors responsible for its maintenance and support as the housing production sector. It was a time when a series of housing developments were produced to meet a growing population demand, but above all to activate the economy through the real estate market.

At the national level, the housing policy model developed during the military dictatorship presented heavy governmental intervention in the process of housing provision. For Arretche (1990, p:23), this area was one of the privileged sectors of the regime that became viable through the creation of a state agency called National Bank of Housing (BNH) that centralized state sector activities between 1964 and 1986.

The creation of $\mathrm{BNH}$ meant concentration-centralization of the housing production process together with the elimination or restructuring of the organs that did not favor this scenario (PEREIRA, 1982, p:26). Government intervention at the time gave rise to a home market divided into two sectors: the middle and high income sector and the low income sector. The first was the object of private agents who had their activities regulated by the State through the $\mathrm{BNH}$ figure while the latter was operated by state promoting agencies in association with private construction companies (ARRETCHE, 1990, p:23).

Within the context of Rio Grande do Sul and more specifically in the RMPA, the Executive Group of the Metropolitan Region (GERM) represented the actors that determined and planned the same. In the early 1970s, the Metropolitan Development Plan (PDM) for the Metropolitan Region of Porto Alegre (RMPA) was approved based on a partnership between Brazil and Germany. The plan arises through a mixed work group, with a german-brazilian composition, in which the technical and financial responsibilities were shared according to a bilateral direction. This document represented a regularization and organization for the urban growth of RMPA considering the following aspects: industry, housing, recreation, collective transportation, sanitation, among others. It sought the implementation of measures and resources for the balanced and integrated development of an area resulting from a historical process of urbanization in small space. This area had a great population growth and economic potential with Porto Alegre, the capital of Rio Grande do Sul, as its main center (GERM, 1973). 


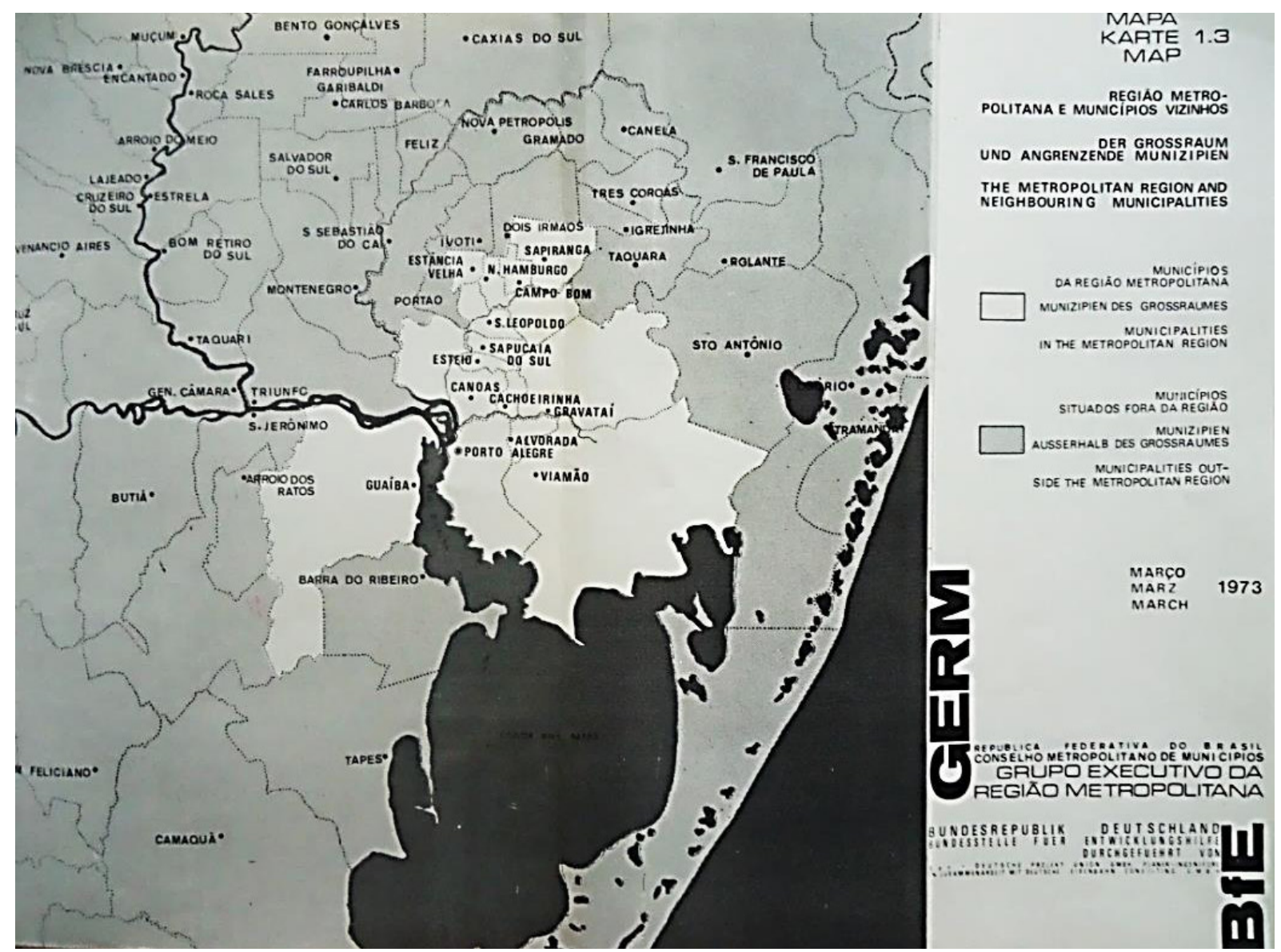

Figure 01

Map of the first 14 municipalities belonging to RMPA.

Source: GERM, 1973

The region consisting of fourteen municipalities was defined using criteria such as the continuity of urban spaces, passenger transport flows and the functions performed by each urban center peripheral to the capital's space (GERM, 1973, p:3). The municipalities present in the original composition of the Metropolitan Region of Porto Alegre (RMPA) were: Alvorada, Cachoeirinha, Campo Bom, Canoas, Estância Velha, Esteio, Gravataí, Guaíba, Novo Hamburgo, Porto Alegre, São Leopoldo, Sapiranga, Sapucaia do Sul and Viamão as shown in the previous image (Figure 01).

Based on this initial configuration and after extensive diagnosis and adoption of the Lowry Spatial Model, nine alternatives were proposed for structuring the RMPA that related residential areas and workplaces (GERM, 1973, p:49). Among these, the chosen one was the third alternative (Figure 02). The objective of this alternative was to distribute the centers along the two road axes that crossed the RMPA (BR-116 and BR290), aiming at a better supply of internal areas and extensive agricultural areas through a reduced number of centralities (GERM, 1973, p:89). 


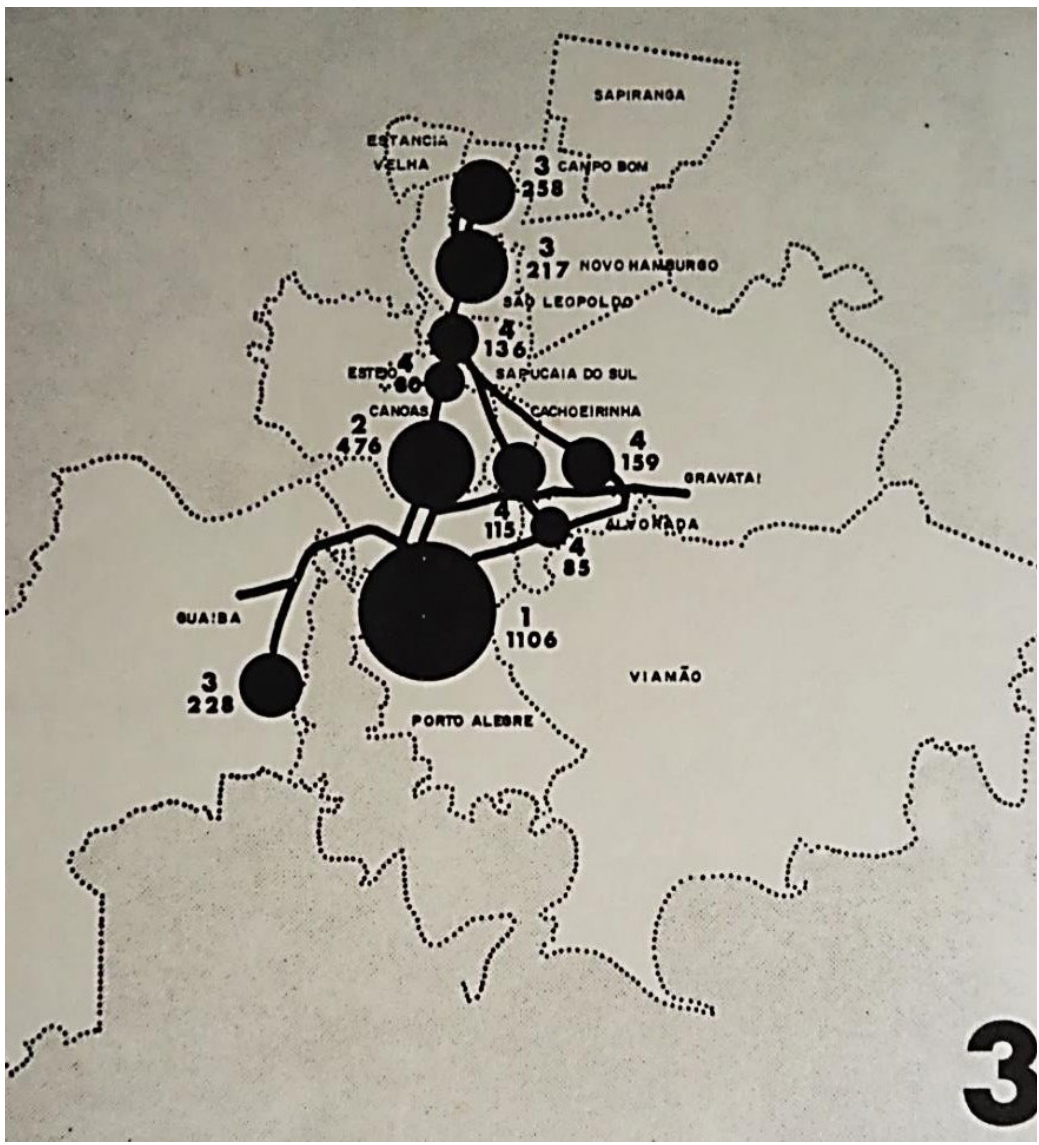

Figure 2

Alternative chosen to organize the RMPA growth.

Source: GERM, 1973

The BNH guidelines together with those of the PDM were responsible for the ordering of the housing production process in the RMPA that materialized in function of the public and private promoters agents. Among the latter stands out the figure of Housing Companies (COHABs) on the public side and the figure of construction companies on the private side. The State in the period between 1964 and 1986 due to the role played by the BNH had a strong participation in the generation of social housing programs and projects. Within this participation, the COHABs were designated by the bank as the promoters of the production of housing for low income. Thought of as mixed-capital companies, these companies operated between the municipal and state levels. They dealt with the range of housing production that did not interest the private sector occupied with the middle and high income sectors, despite the fact that the housing complexes were built through private companies contractors (ARRETCHE, 1990, p:28).

A series of housing complexes was produced through this hegemonic and dominant model in the RMPA by the private and the public sectors, with an emphasis on those produced and implemented by COHAB bet- 
ween the late 1970 s and the early 1980 s as shown in Figure 03. It is evident from the image map that there is a greater number of projects from the private sector than from the public sector, demonstrating the precariousness of the housing system in the low-income area. Therefore, the sets produced by COHAB in RMPA are not the most prominent in the Guajuviras Housing Complex in Canoas/RS analyzed here and marked in red on the map as the public enterprise with the greatest territorial extension.

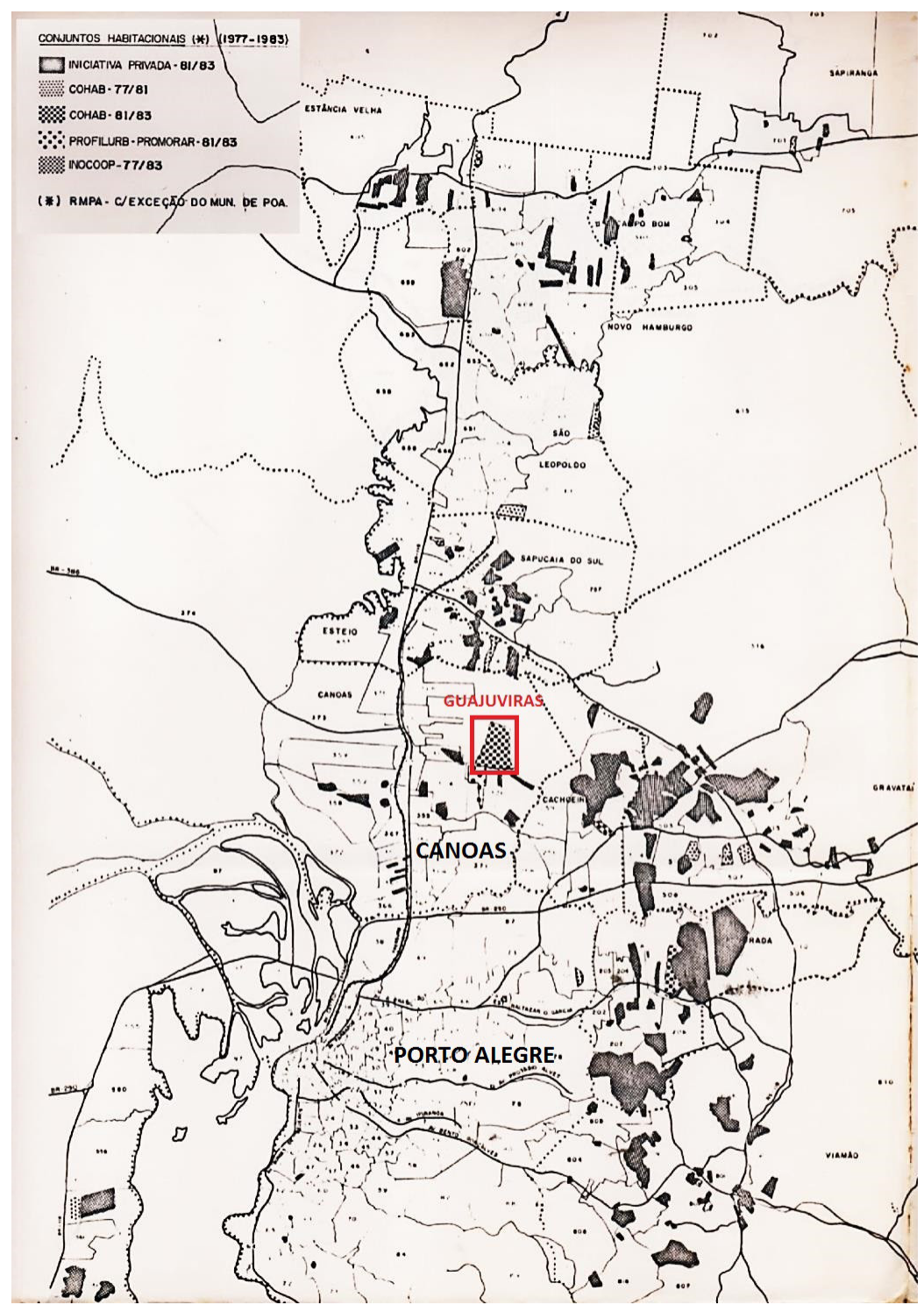

Figure 03

Relation of the sets projected in the RMPA between 1977 and 1983. Source: Almeida, 1989.

Despite the difference in the way that the agencies were involved in the process of production and distribution in the two sectors, the logic for both was the private enterprise. Productivity was the focus of these two forms of housing production that neglected the different local realities. Both $\mathrm{COHABs}$ and private 
companies based production on the mold of industrialized housing. Therefore, the consequence of this procedure was a production of the urban space detached from the actual resident who was disregarded during the productive process, since it was organized in the form of a capitalist production company (DEBIAGI, 1981).

Large population numbers were treated as a numerical demand that needed to be stored somewhere. Such production model symbolized the national scenario and the metropolitan landscape of RMPA. According to Arretche (1990, p:28), despite the significant importance of the Housing Financial System (SFH) in housing production, it is understood that this system was unable to meet the housing needs of the brazilian population. In addition, those who suffered most from this situation were the low-income population that, over time, sought in self-construction, "favelas" and some associative forms the solution for their housing problems and needs. This population corresponds here to the everyday actors who work within the lived space trying to adapt the space conceived by lagged and unfinished projects of some COHABs.

Within this scenario, the question that arises is how do these people overcome such problems by transforming space? The objective is to understand how these different actors manifested themselves and interpenetrated in the perceived space due to the clash between the strategic actions of the mentioned institutions and the tactical actions of the residents. To this end, the historical process of the Guajuviras Housing Complex is emphasized.

\section{Between history and conflicts}

The story built between the design of the conceived space and the daily life of the lived space is illustrated by the clash between the actions of the actors mentioned above. For Certeau (2014), while strategic actions produce a tax and controlling space, tactical actions propose the reinvention of this one by establishing a new production or a silent and astute transformation. Therefore, the relationship between the actors who conceive the project and the actors who live the daily life is permeated by this confrontation between strategic and tactical ones that are manifested in the perceived space of practices. This theoretical problem gains materiality in the historical context of consolidation of housing complexes such as the Guajuviras highlighted below. 
The construction process of the Ildo Meneghetti Housing Complex popularly known as Guajuviras starts in 1974 with the Guajuviras Housing Pre-use Plan. This document was developed by the Government of the State of Rio Grande do Sul under the State Housing Plan (PLANHAP / RS). Based on the guidelines established by GERM, an area was acquired by the State Government called Guajuviras Farm, which underwent a series of preliminary studies aiming at the implementation of the housing complex (PELLEGRINI, 1974). The following year, in continuity with the Guajuviras Housing Pre-use Plan, the Preliminary Design of Neighborhood Unit $n^{\circ} 1$ West was created by the technical team coordinated by the architect Sergio Pellegrini (PELLEGRINI, 1975).

After three years corresponding to the development of the project to be implemented in the territory of the old Guajuviras Farm, in 1978 COHAB entered the municipality of Canoas/RS with the construction project of the Ildo Meneghetti Housing Complex (O TIMONEIRO, June 5, 1992). According to Penna (1998, $\mathrm{p}: 14$ ), the following year, the project was approved for execution based on the Soil Installment Law (Law $n^{\circ}$ $6766 / 79$, article 18). The deployment corresponded to an area of 262.83 hectares divided into six housing sectors. Each sector had a mixed residential plot and a portion of green areas responsible for the connection between the sectors (Figure 04).

No que diz respeito às tipologias habitacionais, estas eram de dois tipos: habitações unifamiliares (casas térreas) e habitações multifamiliares (blocos de apartamentos). A primeira tipologia contava com 4222 unidades distribuídas no interior dos setores habitacionais e a segunda com 1888 unidades distribuídas em blocos de apartamento ao longo da avenida sinuosa central (Figura 04). A construção destas tipologias iniciou e prosseguiu ao longo da década de 1980. Contudo, o processo de implantação do conjunto foi agravado em 1986 quando o BNH é extinto pelo governo do presidente José Sarney (DIÁRIO DE CANOAS, 18 abr. 1998). Tal problemática resultou no abandono das obras do Guajuviras pela COHAB em 1987 devido à extinção do BNH um ano antes e à falência de duas das quatro empresas ligadas a construção do local (DIÁRIO DE CANOAS, 4 jan. 1996; DIÁRIO DE CANOAS, 18 abr. 1998).

With regard to the housing typologies, these were of two types: single-family dwellings and multi-family dwellings. The first typology had 4222 units distributed inside the housing sectors and the second had 
1888 units distributed in apartment blocks along the central winding avenue (Figure 04). The construction of these typologies began and continued throughout the 1980s. However, the process of implementation of the set was aggravated in 1986 when the BNH is extinguished by the government of President José Sarney (DIÁRIO DE CANOAS, April 18, 1998). This problem resulted in the abandonment of the construction of Guajuviras by COHAB in 1987 due to the extinction of $\mathrm{BNH}$ a year earlier and to the bankruptcy of two of the four companies involved in the construction of the site (DIÁRIO DE CANOAS, January 4, 1996; 1998).

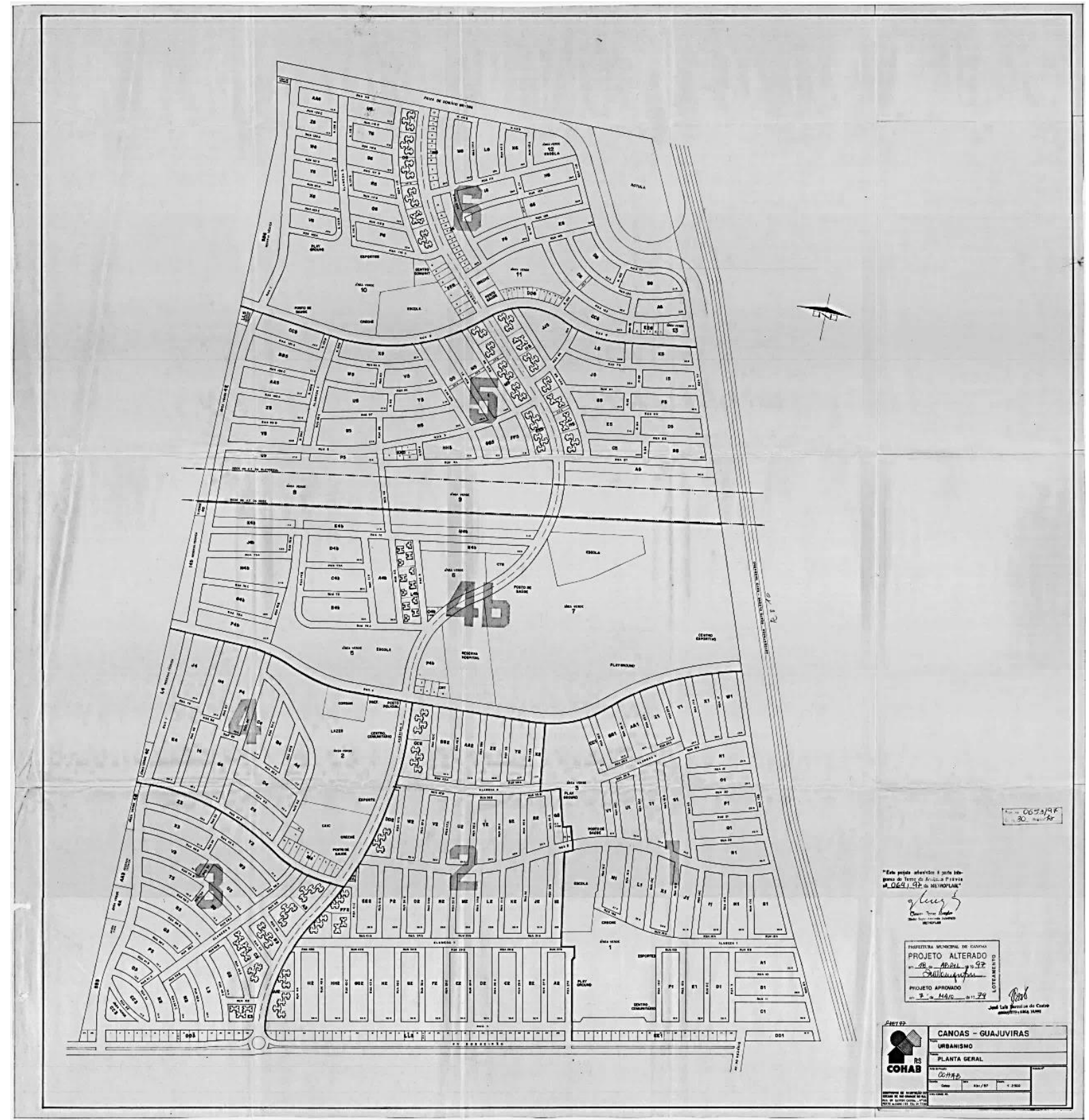

Figure 4

Original implantation dated 1979 of the Guajuviras Housing Complex.

Source: COHAB / RS, 1997. 
The unfinished and abandoned buildings began to suffer structurally with the shutdown of the construction in 1987 as shown in Figure 05. Something needed to be done to that all the investment in the place was not lost due to the problems in the execution of the set. The solution came from the people who were dissatisfied with the situation and occupied the unfinished housing units irregularly, but planned in the same year, on April 17 (PENNA, 1998, p:16).

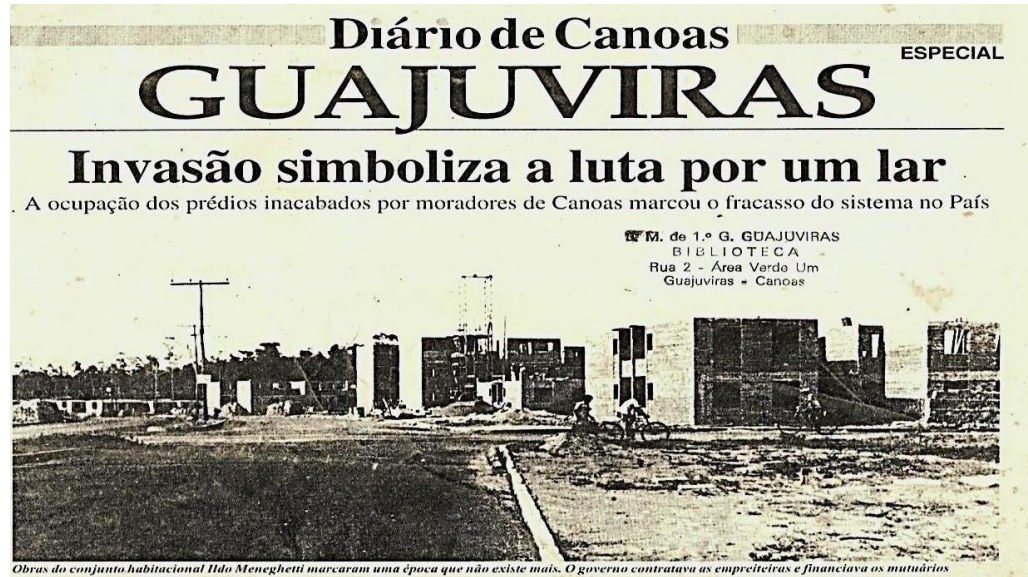

Figure 5

Image of the unfinished construction.

Source: Library of the Guajuviras 1st Grade Municipal School.

After the occupation, the Occupation Commission of the Guajuviras Housing Complex and the Residents Association of the Guajuviras Residential Complex and a system of articulation and representation were created (PENNA, 1998, p:44; ZACHER, 2003, pp:30$31)$. These two groups played a key role in informing and organizing the residents who occupied the abandoned set with regard to their rights (Figure 06).
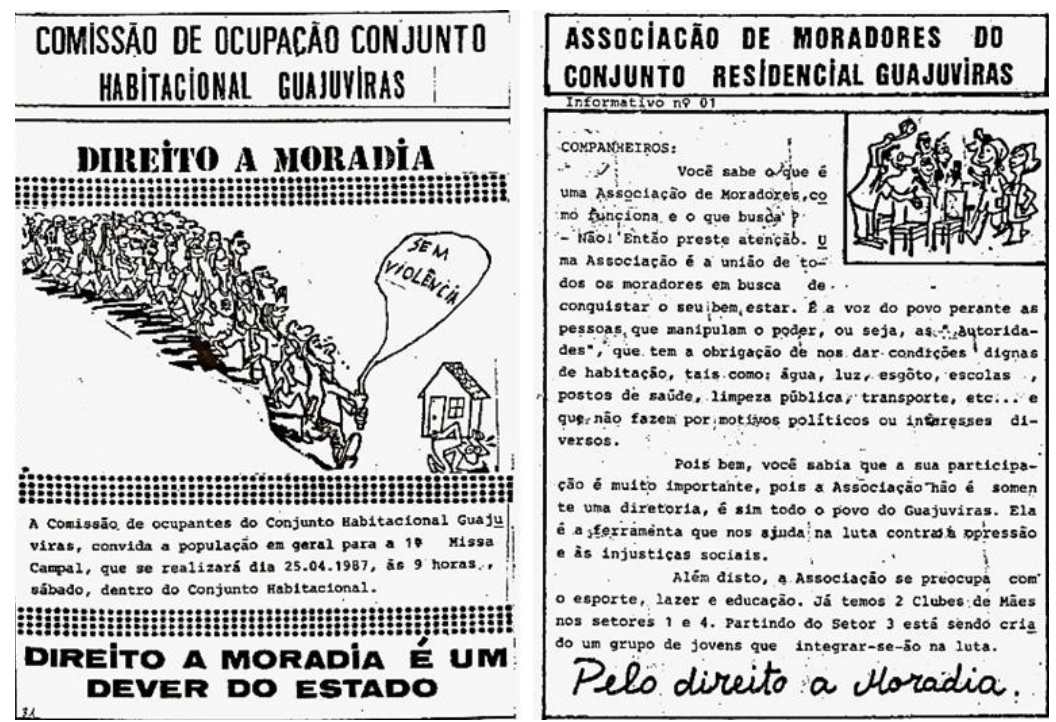

Figure 06

Informational free of charge for residents.

Source: Zacher, 2003. 
The first months after the occupation were the most turbulent. Within the housing complex, the struggle to maintain the possession of the houses abandoned until then was developed. According to Zacher (2003, p:23), the nights were unpredictable and it was necessary to wake up every three hours to change the candles that were fundamental to avoid the house invasion during the night. As the houses and apartments were occupied irregularly and the Brigade hampered free access at the outset, daily improvisations and bonds of friendship between the occupants were central to the survival there. The collective emerged in relation to the individualities according to basic needs such as food (ZACHER, 2003, pp:24-27). One helped the other in strengthening ties that supported the occupation from the beginning. But despite their companionship, the absence of basic infrastructure aggravated the desperate and precarious situation of the occupants.

The difficulties did not end with the occupation, but they were just beginning. It was then up to the authorities to try to make the living conditions of the new inhabitants more human (PENNA, 1998, p:22). However, the issue of land regularization and permanent tenure of housing were still outstanding issues. According to the Residents Association, the values stipulated by COHAB for the payment of benefits did not correspond to the economic and social reality of the occupant group. Between ill-fated negotiations, the pressure continued on the part of the public sector while the residents remained resistant until the final agreement between the parts in the month of April of 1989 when the occupation completed two years of existence (ZACHER, 2003, pp:138-142). The assembly that approved the agreement happened in May of the same year.

The beginning of the decade of 1990 symbolized the consolidation of the struggle for the own dwelling of the occupants of the Guajuviras Housing Complex. It was the time when the struggle for improving the neighborhood's infrastructure intensified. The qualifications of water supply, electricity, sewerage, garbage collection and transportation were the main demands (PENNA, 1998, pp:27-31). Throughout this decade, local commerce that was not legalized began to gain strength with the emergence of several establishments along the blocks as shown in Figure 07 (PENNA, 1998, p:37). 


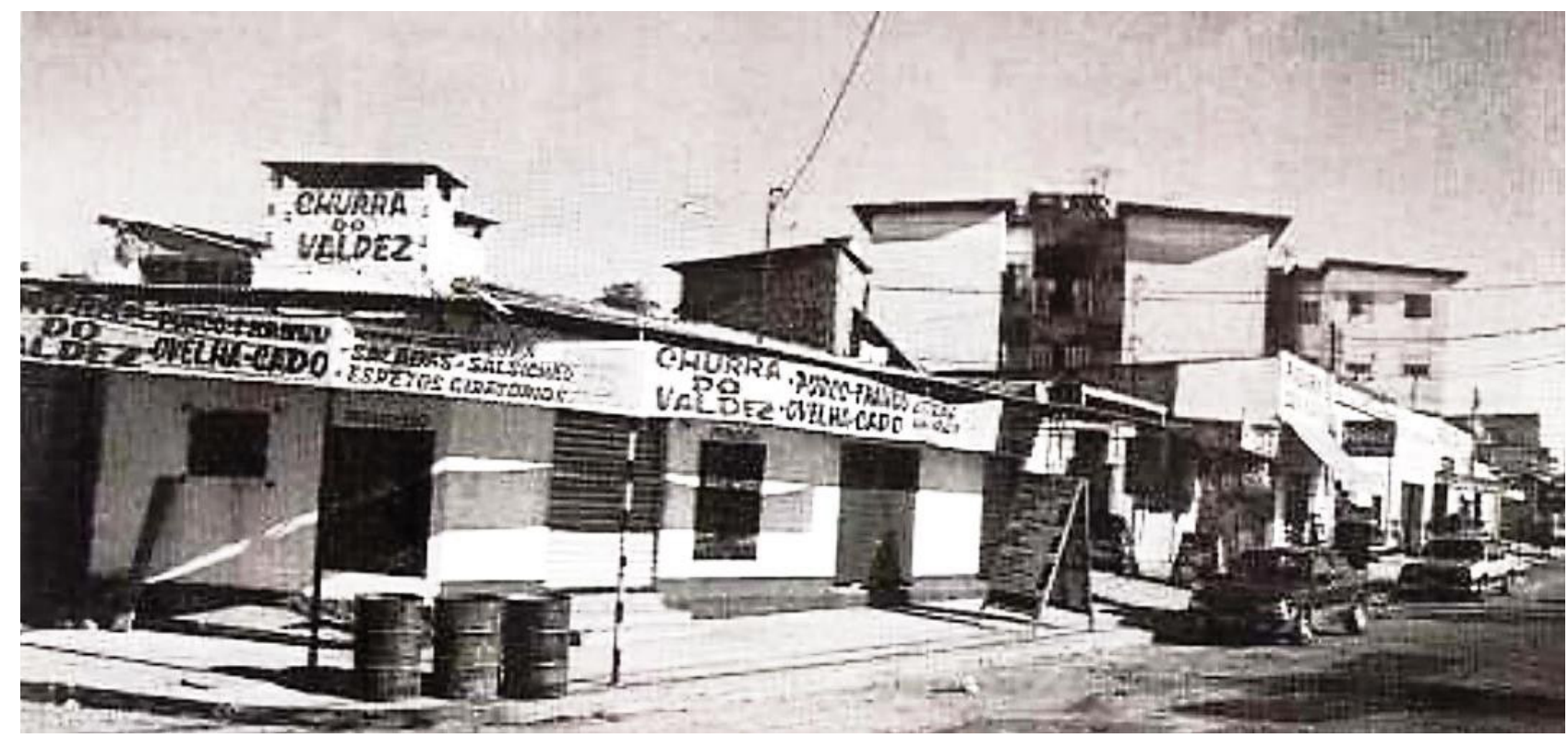

Figure 07

Several small trades on the main avenue in 1998.

Source: Penna, 1998.

In spite of the stability acquired by the occupants in accordance with the agreement with $\mathrm{COHAB}$, the place did not fail to present conflicting situations regarding land tenure, because in 1992 the process of irregular occupation of the green and public areas began (PENNA, 1998, p:31). These occupations that continued throughout the 1990s were known as sub-occupations and present precarious urban conditions to the present day despite some improvements such as garbage collection, water supply and electricity.

As a result of the COHAB liquidation process in 1995, the Guajuviras was donated by the State Government to the municipality of Canoas, which became responsible for improvements and regularization of the situation of borrowers who had irregular ownership of the land. With the registration of the properties in the city hall and the definition of the issue of license permits for irregular trades, the housing complex could be formalized as a neighborhood of the city of Canoas (DIÁRIO DE CANOAS, July 22, 1995). The end of the decade of 1990 was conflicting in the Guajuviras, because it corresponded to a new series of invasions in the green areas. The new invaders justified themselves by saying that they did not want to earn the lands that were used to gather garbage, bandits and dead animals (DIÁRIO DE CANOAS, March 23, 1999). True "mutirões" were carried out by the new occupants who wanted to build their houses in the occupied, demarcated and cleaned areas by them (Figure 08). 

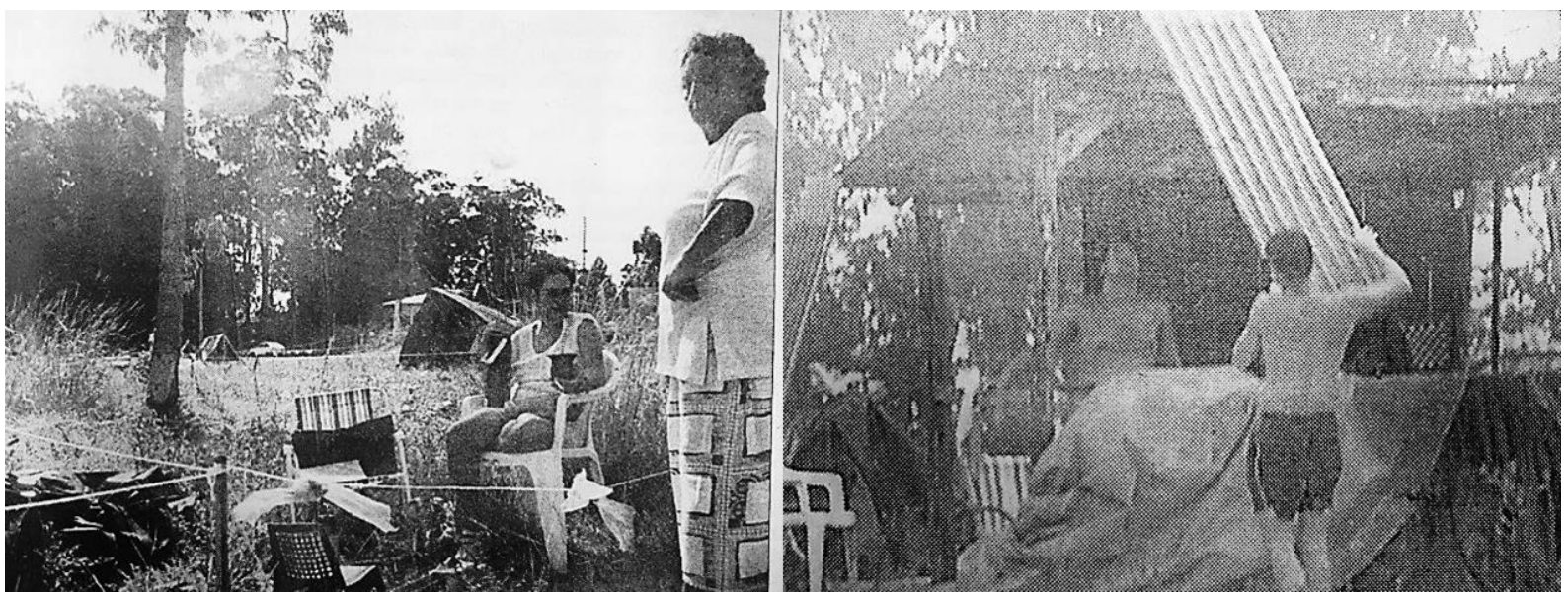

Figure 08

Residents of sub-occupations of green areas.

Source: O Timoneiro, 1st Apr. 1999 and Diário de Canoas, April 3. 1999.

This situation generated a tension between the new occupants and the established neighborhood from the initial occupations of Guajuviras (DIÁRIO DE CANOAS, March 25, 1999). In the midst of these turbulent issues, 6300 properties of the initial occupation were regularized by the city hall, enabling the collection of the IPTU (DIÁRIO DE CANOAS, June 14, 1999). The 1990s ended with the Censo 2000, which ranked the Guajuviras as one of the most populous neighborhoods of the RMPA with 32.000 inhabitants, considering the original Ildo Meneghetti Housing Complex and the invasions of the surrounding area (DIÁRIO DE CANOAS, December 7, 2000).

The beginning of the 2000s was marked by the prioritization of the land regularization process of the occupations of the green areas (Figure 09). According to the Secretary of Housing of the time, these areas surprisingly already had minimal infrastructure for the urbanization of the land because the occupation was organized in lots which facilitated the implementation of basic sanitation. Therefore, the funds that would be used in the expropriation could be used in the regularization and the infrastructure of the parcels (O TIMONEIRO, March 9, 2001).

In 2003, the Ildo Meneghetti Housing Complex was finally transformed into Guajuviras District, due to the bill 053/02 of the executive, which changes the legislation on the denomination and location of the districts of Canoas (DIÁRIO DE CANOAS, January 13, 2003). In this period, the situation of the defaulting borrowers who did not have the conditions to pay their debt with the Federal Savings Bank, which acquired COHAB's real estate credits, is aggravated (DIÁRIO DE CANOAS, May 26, 2003). 


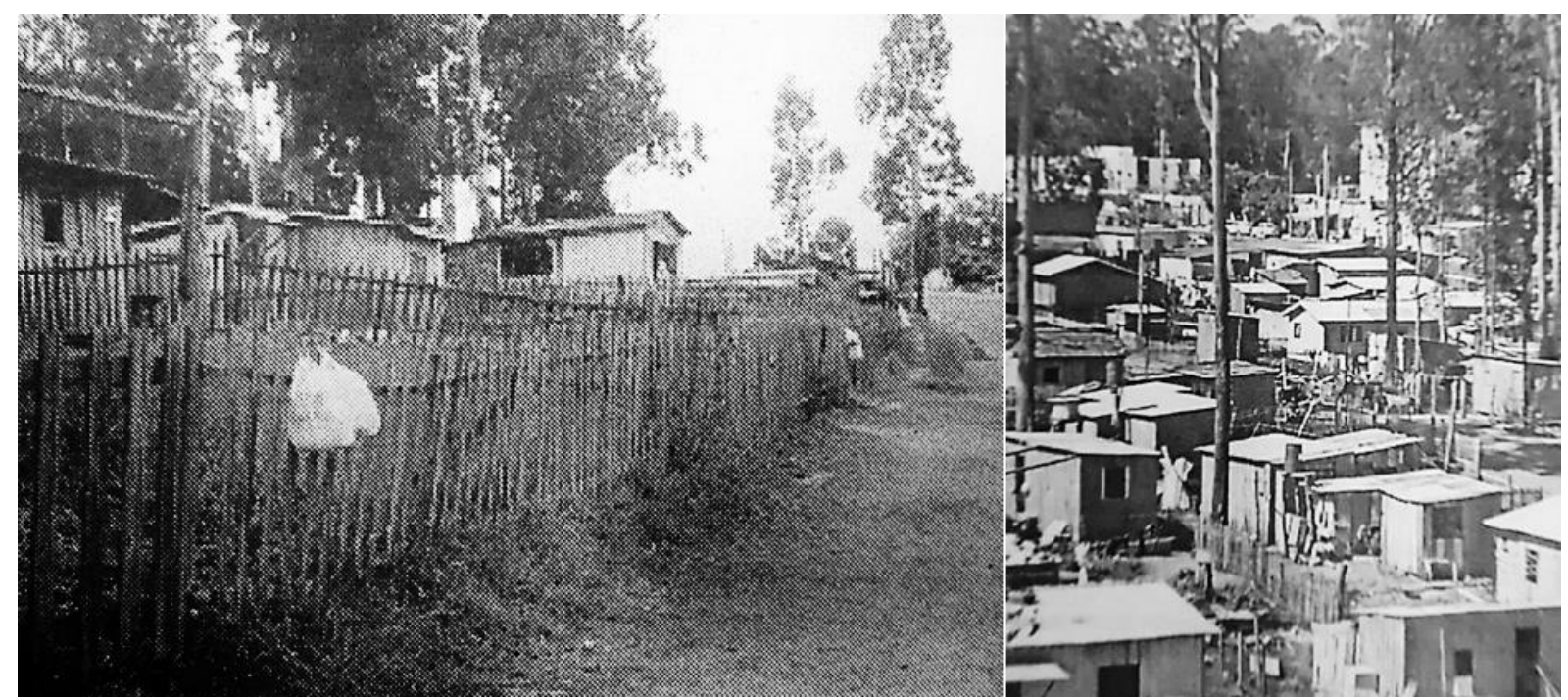

Figure 09

Urban fabric of sub-occupations of green areas.

Source: O Timoneiro, March 9, 2001 and Diário de Canoas, April 13, 2001

From the year 2004 onwards, the Guajuviras experienced a period of affirmation of the local imaginary in function of several remarkable places and events occurred in the place. The 14th Solidarity Action was held at Guajuviras, surpassing the number of previous year's visits (DIÁRIO DE CANOAS, April 20, 2004). The relevance of public leisure areas and educational institutions was evidenced due to the association of these places with the most important points for the residents (DIÁRIO DE CANOAS, May 8, 2004). After the 24th anniversary of the initial occupation, residents comment on the evolution of the neighborhood due to the union between the people (Figure 10). Everyone is known according to the residents that emphasize their affective memories related to the neighborhood affectionately called "Guaju" (DIÁRIO DE CANOAS, April 16, 2011).

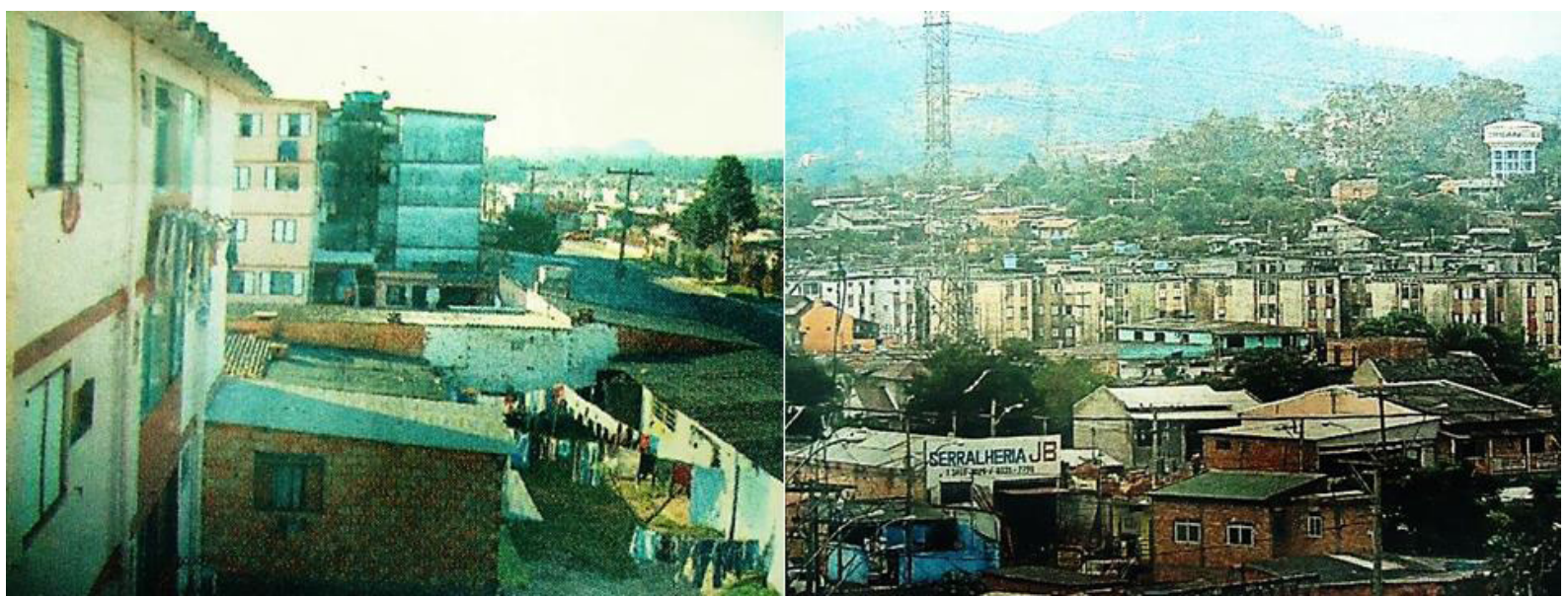

Figure 10

Guajuviras set transformed in time.

Source: Diário de Canoas, January 22, 2005 and Diário de Canoas, April 16, 2011. 
The housing policies and metropolitan plans of the period of the military dictatorship were no longer valid but left scars. The Ildo Meneghetti Housing Complex can be considered as one of these scars still to bleed in the daily life of the residents who seek according to their possibilities to reinvent and adapt the space to their behavioral habits. Currently the neighborhood still faces difficulties stemming from a troubled consolidation process. Within this trajectory, a series of convergences and divergences between the actions of the hegemonic actors responsible for the initial production and for the land regularization and the actions of the daily actors responsible for the successive occupations stand out. Based on the reconstruction history carried out, it aims to materialize, next, an analysis of the spatial repercussions in the daily life as a function of the structure-formfunction indicator.

\section{Between the spatialities and their differences}

The spatial results and their daily repercussions resulting from the clash between strategies and tactics in the perceived space can be qualified according to the relation between structure, function and form. For Lefebvre (2001), when a space undergoes certain functional and formal changes, it may present structural maintenance or structural transformation. In the first case there is continuity or a greater correspondence between the project and the transforming daily life, while in the second there is discontinuity or a lesser correspondence between the two. These different situations built over time have repercussions on the daily dynamics of each place. Such theoretical relations enable an analytical look at the different realities that change over time, acquiring different meanings as in the case of the Guajuviras Housing Complex, analyzed below.

The Ildo Meneghetti Housing Complex located in Canoas/RS was one of the many housing developments that "sprouted" overnight in the RMPA territory. In order to meet the low income range, a large number of single-family homes and multi-family blocks were designed within $\mathrm{COHAB}$ and constructed by private builders (Figure 11).

Based on the BNH policy and the spatial guidelines of the PDM, these large enterprises started to receive a considerable population contingent within 
the expanding metropolitan territory. However, receiving is far from sheltering and protecting, since these constructed spaces were designed to meet a quantitative demand disregarding the specificities and identities of the social groups of the lived space. From this situation arise the conflicts, because the spaces are not only the physical surfaces that make up the public and private spaces, but also the different social groups that inhabit them and transit between their surfaces guaranteeing their particular meanings. This problem is present in the critiques of Turkienicz (1984), Luccas (1984/85) and Rigatti (1997) rescued in Sanvitto (2010).

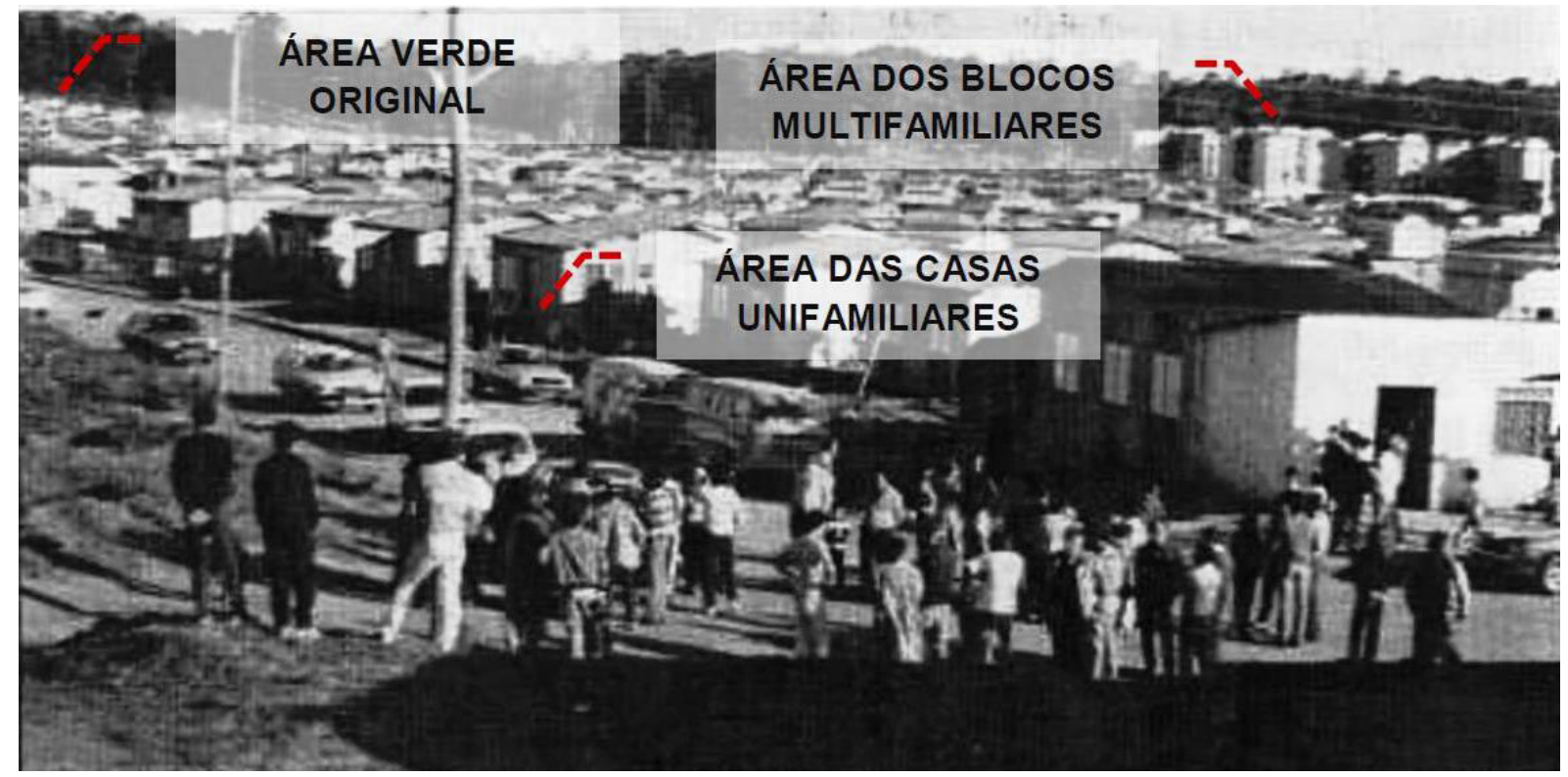

Figure 11

Dwellings (single-family and multi-family) and green area in the background originally.

Source: Penna, 1998.

Part of this problematic context, the Guajuviras Housing Complex was irregularly occupied as other popular housing developments in the RMPA. The occupation was celebrated as a victory of the tactical actions of the workers who had the direct possession of the dwelling against the hegemonic and strategic power of the COHAB that tried in several ways to avoid the occupation. The clashes between the hegemonic actors and the everyday actors were constant in the consolidation of the neighborhood, representing a fundamental part of their particular history after the occupations (ZACHER, 2003).

When the occupations began, the space conceived in a given moment of the past transformed itself in function of the space lived in the time. However, such a transformation did not mean the complete elimi- 
nation of the first by the second, for what happened was an interpenetration of different times. At the time of the implanted project, the successive times of the occupied occupations interpenetrated, producing a new space different from the one originally conceived. Therefore, tensions and conflicts arose from this shock that is both spatial and temporal and that is evidenced in the perceived space with respect to the actions of the project and the actions of daily life. Part of the original structure remained and part was restructured through formal and functional transformations producing a true mosaic of urban changes.

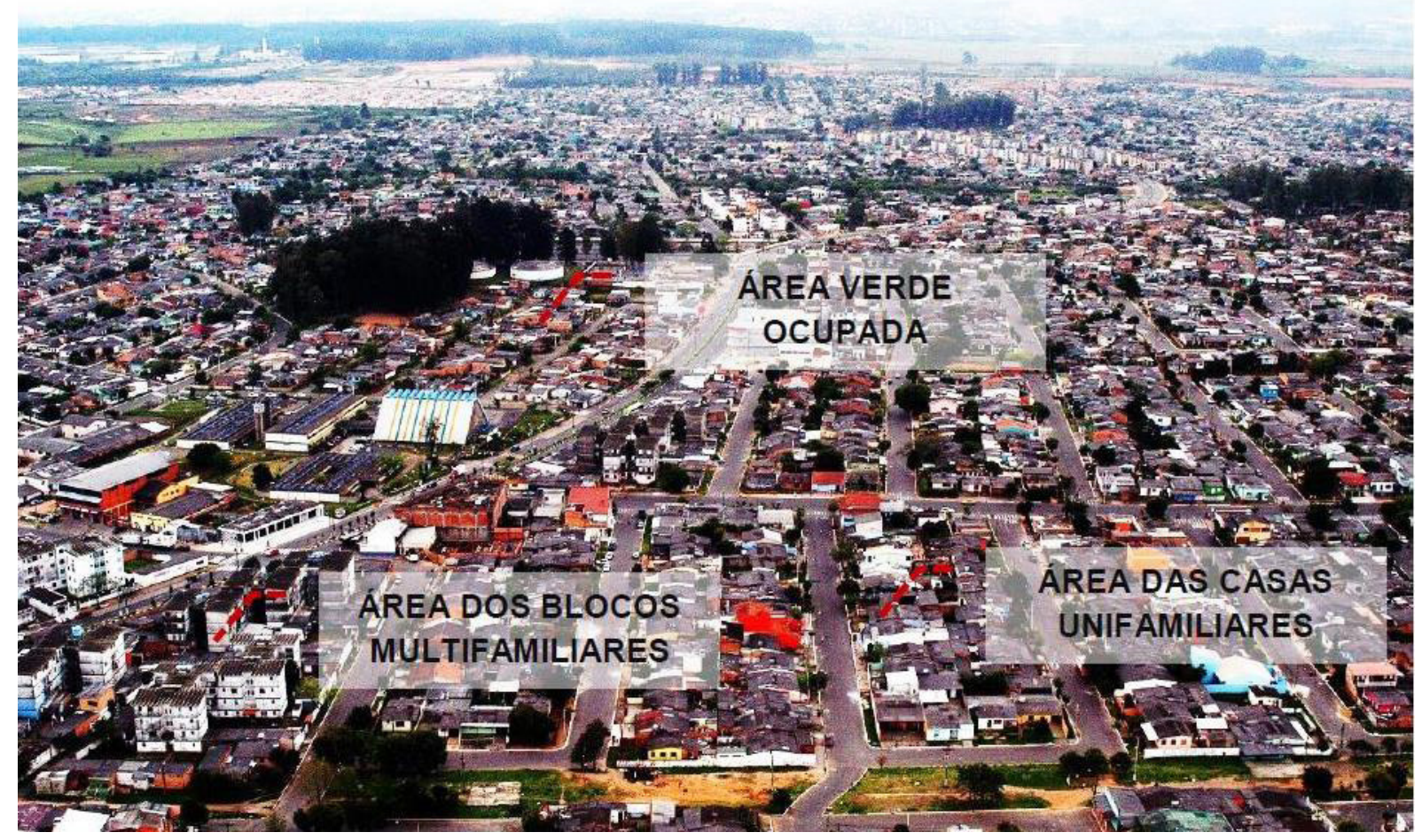

Figura 12

Imagem do Guajuviras transformado pelos moradores.

Fonte: César Barbosa, 2009

The Figure 12 shows some of these interpenetrations resulting from the demographic and constructive density acquired throughout the occupations. In this temporal path, the space was appropriated, transformed and resignified by the inhabitants in different ways that broke with the imprisoning logic of the homogeneous "cells of the house" presented in Luccas (1984/85, $\mathrm{p}: 3)$. Additions and subtractions have structurally manipulated the conceived space of the project giving rise to the lived space of appropriations over time. Those who knew the original project and enter the transformed neighborhood today tend to experience a clash of realities because the dynamics are completely distinct due to the overlap between spatial continuities and discontinuities. 
As the image in Figure 12 shows compared to the image in Figure 11, there are a variety of manipulation's forms of the project as a function of everyday life within the Guajuviras District. These forms produced a mosaic that is evident in the extent to which the implanted project is compared with the transformative occupations over time through the structure-formfunction indicator. Based on this indicator it is feasible to understand the continuities and discontinuities between the actions of the project and those of the daily life. Within this approach, three distinct patterns of spatial transformation are highlighted as a function of social appropriation: the areas of single-family houses, the areas of multi-family blocks and the irregularly occupied green areas.

\section{The areas of single-family homes}

These are the stretches in which the structures presented a greater continuity or a greater convergence between the original project and the appropriations in the time. Functional and formal transformations here did not represent a disruption of the originally designed by the temporally appropriate, but a qualification of the space that gained in diversity, attractiveness and constructive density. Basically geared towards residential use due to the isolated houses on their lots at the beginning of occupations, the areas of single-family homes retained their original structural vocation with some functional and formal additions or subtractions that improved people's daily lives. These parcels of the neighborhood, representing the largest occupied area of the complex, are a good example of functional and formal plasticity in respecting the structure initially designed and implemented. In addition to single-family houses, within this group are some commercial areas and squares that also maintained their original structure counting on functional and formal additions over time. On the commercial side, these are some discrete points distributed throughout the set. The squares areas represent contrasting oases of public use in the middle of the urban space of the neighborhood. They are some residual spaces remaining of the public areas originally implanted and that stand out by the preserved vegetation. These small public places in relation to the neighborhood are also an example of convergence between the conceived and the lived as well as the occasional trades.

\section{The areas of the multi-family blocks}

This part of the neighborhood presents a partial rupture of the original structural order. Here there is a 
mixture of divergences and convergences between the projected in the past and the appropriate over time differently from the previous case where convergences predominate over divergences. The free spaces of this part of the set corresponded in principle to the garden retreat of the four-story blocks isolated in the center of the lots. However, over time, these spaces were gradually being occupied by garages, shops and varied services in function of the centrality in relation to the set as a whole. These elements have arisen over time due to the daily demands not met by the unfinished project. While the function and the form in these areas of the set were restricted to the residential use and the housing blocks in the original implantation, after occupations the other uses were added as well as their characteristic volumes in the periphery of these lots. Thus, functions and forms related to multi-family blocks remained in space, but with the addition of functions and forms associated with garages, shops and services resulting in a structural mix. This structural mix promoted a formal and functional diversity that transformed these central spaces of the neighborhood into areas deeply moved and activated by local residents and also by outsiders in daily life.

\section{The green areas occupied}

Unlike the first case in which the convergences or continuities were predominant and the second in which there was a mixture of continuities and discontinuities between the project and the appropriation, here the discontinuities stand out. We observe a structural break evident in these spaces projected as a function of the successive appropriations in time. Most of the spaces that would initially meet the collective requirements of the community through areas of common use were appropriated and irregularly parceled up until the present day from the sub-occupations that occurred in a second moment of the occupations. The large green areas, where only the schools were installed, were reduced to eucalyptus bushes in the implementation of the original project, making community and leisure activities impossible. Therefore, these areas were occupied and restructured based on residential and irregular use as well as some stretches of local pedestrian crossing. The function of collective exchange and coexistence was replaced by the function of private residence associated with precarious housing forms and their poor housing conditions. Over time, such irregular residences were qualified by the residents and the public sector due to the increase of infrastructures such as electricity, water and sewage. However, they still have lower living conditions than the rest of the neighborhood. 
These three areas of the Guajuviras present distinct structural relations between the project and the quotidian due to the functional and formal transformations. The result of these distinctions is a mosaic of borders between the public and the private that are manifested in everyday life in different ways. While in the areas of the blocks such frontiers promoted the approximation among the residents of the neighborhood over time from the formal and functional transformations, in the green areas occupied occurred the remoteness. Unlike the areas of single-family homes that retained their original structure and, therefore, the premises of the project, in the two previous cases, these were broken by the transformations in the daily life. However, the result physical and social was quite different between both. While those who live in the blocks are inserted in a daily dynamic integrated to the city due to a diversified and busy structure, those who live in the green areas occupied are experiencing a dynamic on the edge of the city due to a structure that is not very accessible and also precarious in terms of infrastructure.

\section{Conclusion}

The housing policy in Brazil between the 1970s and 1980 s gained materiality in the daily life of the housing complexes that were implanted at that time in function of a project and occupied over time. Therefore, it is between these moments that the spaces are constructed and transformed generating different relations between the inhabitants. The case studied here is a good example of this relational diversity, because the consolidation period of the Guajuviras started with the project and always partially closed in the daily life is marked by evident contrasts between the spaces of the physical and social points of view. So, when looking at how the projected space is transformed by the inhabitants in the daily life, it is feasible to understand the degree of correspondence between both and the repercussions in the daily life of the inhabitants.

The three areas analyzed here show this scenario in which the transformation of the original project into the daily life gives rise to three different neighborhoods. The area of single-family homes was the one that presented a greater correspondence between project and daily life while in the occupied green areas and in the areas of the blocks the opposite occurred. In the first case the original structure was maintained during the formal and functional transformations, already in the following two cases this one was transformed also. However, although the changes altered the structure in the latter two, the daily repercussions were not the 
same, because while in the blocks emerged a dynamic of daily approximation among the people, in the green areas occupied the dynamics was of remoteness. Therefore, the structural rupture resulting from transformations between the project and the daily life does not represent in itself a barrier to the daily necessities, but a change in the previously projected situation that can provide an improvement or not in the conditions of life.

In this context, the changes proposed by the architecture of daily life leave several lessons that deserve to be highlighted. The way that the space is reinvented by the actors who live the daily life represents the revision of a project and of a housing policy in function of the search for better living conditions. However, this reinvention is not seen in such a way by the hegemonic actors who conceive projects and policies. Instead of looking at these transformative actions as a possibility of renewal of the old-fashioned housing guidelines that are still in force, the latter qualify these actions as informal proposing the fight against them and not the conciliation from them.

\section{References}

ALMEIDA, M. S. de. Políticas Públicas da Habitação e do Transporte: O Caso da Região Metropolitana de Porto Alegre. 1989. 288 f. Dissertação (Mestrado em Planejamento Urbano e Regional) - Programa de Pós-Graduação em Planejamento Urbano e Regional (PROPUR), Universidade Federal do Rio Grande do Sul (UFRGS), Porto Alegre.

ARRETCHE, M. Intervenção do Estado e setor privado: o modelo brasileiro de política habitacional. Espaço \& Debate, São Paulo, n. 31, p. 21-36, 1990.

CERTEAU, M. de. A invenção do cotidiano: Artes de fazer. Petrópolis: Vozes, 2014.

COHAB/RS - Companhia de Habitação do Rio Grande do Sul. Memorial descritivo e implantação original do Conjunto Habitacional Ildo Meneghetti. Canoas, 1997.

DEBIAGI, M. C. A produção e consumo da habitação. Projeto, São Paulo, n. 29, p.12-14, maio 1981.

GERM - Grupo Executivo da Região Metropolitana e Deutsche Projekt Union. Plano de Desenvolvimento Metropolitano: Sinopse. Porto Alegre: GERM, 1973.

LEFEBVRE, H. The production of space. Oxford: Basil Blackwell Ltd, 1991.

LEFEBVRE, H. O direto à cidade. São Paulo: Centauro, 2001.

LUCCAS, L. H. H. A desconsideração dos padrões culturais do usuário em planos habitacionais. 1984/1985. 9 f. Monografia (Mestrado em Arquitetura) - Programa de Pesquisa e PósGraduação em Arquitetura (PROPAR), Universidade Federal do Rio Grande do Sul (UFRGS), Porto Alegre.

PELLEGRINI, S. E. Pré-plano de utilização do Conjunto Habitacional Guajuviras. Porto alegre: PLANHAP/RS, 1974. 
PELLEGRINI, S. E. Anteprojeto da unidade de vizinhança - 1 oeste. Porto alegre: PLANHAP/ RS, 1975.

PENNA, R. Canoas - Para lembrar quem somos: Guajuviras. Canoas: SMEC-DPESA, 1998.

PEREIRA, L. H. Habitação popular no Rio Grande do Sul 1890/1980. Porto Alegre: Cadernos do PROPUR/UFRGS, 1982.

RIGATTI, D. Do espaço projetado ao espaço vivido: modelos de morfologia urbana no Conjunto Rubem Berta. 1997. 340 f. Tese (Doutorado em Arquitetura e Urbanismo) - Faculdade de Arquitetura e Urbanismo (FAU), Universidade de São Paulo (USP), São Paulo.

SANVITTO, M. L. A. Habitação coletiva econômica na arquitetura moderna brasileira entre 1964 e 1986. 2010. 539 f. Tese (Doutorado em Arquitetura) - Programa de Pesquisa e PósGraduação em Arquitetura (PROPAR), Universidade Federal do Rio Grande do Sul (UFRGS), Porto Alegre.

TURKIENICZ, B. A forma da cidade - Agenda para um Debate In: TURKIENICZ, B. (Org.). Desenho urbano I - Cadernos Brasileiros de Arquitetura. v.12. São Paulo: Projeto, 1984. p. 9-26.

ZACHER, L. C. Guajuviras - Diário de um ocupante. Canoas: Tecnicópias, 2003.

\section{JORNAIS RELACIONADOS}

DIÁRIO DE CANOAS. Canoas: Editora do Diário de Canoas, 1995 a 2011.

O TIMONEIRO. Canoas: Editora de O Timoneiro, 1992 a 2001. 